\title{
THE PHENOMENON OF MULTICULTURALISM. THE CASE OF POLAND'
}

\author{
Anna Śliz \\ Marek S. Szczepański
}

\begin{abstract}
One of the most important global processes nowadays is migration. Its result is, inter alia, the deepening multiculturalism. It can take the form of a social phenomenon, political project or society. In this article we have focused on multiculturalism as a social phenomenon. It means the presence of different cultures with an ethnic background of their diversity in a specific social space and historical moment. They exist together and accept the mutually distinct ethnic (cultural) difference. The origins of the phenomenon of multiculturalism go back to ancient times, although then the phenomenon did not have a scientific framework of analysis. Such ones appeared in the 70s and 80s of the twentieth century. An example of a society in which multiculturalism is present is modern Poland.
\end{abstract}

\section{Keywords}

multiculturalism, ethnic groups, national and ethnic minorities, Poland

\section{Multiculturalism, what is that?}

Since the 1970s and 1980s, the interest in multiculturalism has increased. At that time its first studies appeared. Still, they were accompanied by theories, concepts and ideas worked out in the past, such as assimilation, segregation, or cultural pluralism (Rokicki,

\footnotetext{
${ }^{1}$ In this article fragments of the first chapter of the book by Anna Śliz, Wielokulturowość: stygmat współczesnego świata? Próba analizy socjologicznej [Multiculturalism: stigmata of the contemporary world? An attempt of sociological analysis] were used (the book submitted for publication in the UO Publishing House in May 2017).
} 
1996). Particularly important were the assimilation ideologies, which fail both in the United States and in Australia, paved the way for cultural pluralism and multiculturalism. At first the interest in multiculturalism started in societies shaped by the immigration process. They were Canada and Australia, which in the 70s adopted, as the foundation of existence, the official policy of multiculturalism. It is based on three pillars: "the equality in the treatment of all citizens in the opportunities for individual and collective development, the abolition of racial barriers and the right of individual minority groups to define and express their unique cultural heritage and identity, among which special place is occupied by language and religion" (Zubrzycki, 2000, p. 229). The United States is led by pluralism. It means the conscious effort of minority groups, combined with the state's permission to uphold their ethnicity, while simultaneously seeking to occupy a prominent place within the dominant group (Sadowski, 1999, p. 34). Cultural pluralism therefore means the social movement of minority groups, aimed at preserving their distinctiveness within the dominant culture.

Today, the interest in multiculturalism is centered mainly on Western European countries and increasingly Central-Eastern Europe. This is connected with the increasing number of refugees and immigrants arriving on the Old Continent. This situation is perceived as an important cause of many problems, including, above all, terrorist acts. The events in France, Belgium or Germany confirm such a thinking. Contemporary interest in multiculturalism helps its unequivocal understanding. It is important to point out three basic concepts of multiculturalism in the context of different social spaces. It is multiculturalism as a social phenomenon, a political project, and multicultural society. The topic of this article will be multiculturalism as a social phenomenon. Let's just say that multiculturalism is "an ideology and a policy of respecting and harmonizing cultural differences in the area of a given country" (Golka, 2007, p. 224). It is a trial to help the ethnic (cultural) groups, who are aware of and emphasizing their distinctiveness, are demanding a law guaranteeing the equalization of their cultures with the dominant culture in the public sphere. Political projects have become an important element of Western states' policy. Multicultural society is the one "that is uniform in the public sphere but encourages diversity within what is considered private or common " (Mucha, 2005, p.53). Multicultural society is "an open society that has achieved a high degree of institutionalization and dynamics of cultural diversity and is prepared to make full use of the benefits and because of that has no special problems" (Sadowski, 2011, p. 58). In today's world there are two fully formal multicultural societies. It is Canada, whose government has adopted the general assumptions of federal multicultural policy presented in the form of "the Multiculturalism Act" and adopted by the Parliament in 1971. The Prime Minister was Pierre Elliot Trudeau of the Liberal Party (Debates. 12 October 1971). And it is Australia, whose government in 1977 adopted the report "Australia as a Multicultural Society" (Australian Ethnic Affairs Council, 1977). This is a document that sanctioned Australian multiculturalism. It was defined as a social cohesion that guarantees: equality, cultural identity, and policy to implement these values. 


\section{Multiculturalism as a social phenomenon}

Florian Znaniecki recognized sociology as a science of social phenomena that exist and change as a result of the actions of individuals and groups. They are clearly separated from natural phenomena. Social phenomena are linked to a specific cultural system "that exists for certain conscious and active historical entities, i.e. in the sphere of experience and activity of a certain people and communities living in a specific part of the human world in a particular historical age [...] a cultural system is really and objectively, what was (or is) given to those historical subjects when they experienced (or are experiencing) with it actively being dealt with" (Znaniecki, 2008, pp. 67-68). Each cultural system exists when it is manifested in human activities. In multiculturalism, the point is in a social space, containing several cultural systems. Most often there is one dominant system and minority systems. They are made up of ethnic (cultural) groups and their members. This is the occurrence of different cultures with different ethnic background in a particular space and historical time. They exist together and accept each other's differences. Such social reality is characterized by the phenomenon of multiculturalism, which in this article is of exclusively ethnic character (Mucha, 1999)2. This means, firstly, the state of visible cultural diversity of the society and the noticeable identity of the people shaped by their belonging to cultural groups. Secondly, the level of social awareness towards various values and norms and the realization of the various cultural practices manifested by people in everyday life. Thirdly, the ideological system that integrates cultural diversity into social practice (Mucha, 1999, pp. 41-50). Ethnic multiculturalism, then, is not a simple cultural differentiation, but the coexistence of groups consisting on "naming their incommensurability, emphasizing boundaries and different identities, whose behavior requires a policy of identity based on the difference" (Hałas, 2015, p. 19). Each ethnic group strives to preserve its own culture. Its members take steps to preserve the foundation of the axiological and normative systems. It is about preserving an ethnic (cultural) identity. These groups are simultaneously entering the dominant culture system, making its more or less distinctive elements. This is a phenomenon that constitutes the specific conditions of a particular social reality supported by ethno-cultural groups (Ivison, 2010, p. 2). The phenomenon of multiculturalism is one of the most important phenomena of the modern world. It is dynamic. Migration movements promote the differentiation of racial, ethnic, religious and linguistic spaces. At the same time people living in such spaces experience these differences in everyday life.

The sine qua non condition of the existence of multiculturalism is the common occurrence of separate groups with diverse ethnic background. Tadeusz Paleczny writes: "Multiculturalism is a phenomenon consisting of the coexistence of two or more groups with separate languages, religions, customs, traditions and systems of social organization on the boundaries of the state-territorial borders. The coexistence of cultures is a consequence

\footnotetext{
2 Janusz Mucha writes about ethnic and non-ethnic multiculturism: Janusz Mucha, Wielokulturowość etniczna i nieetniczna, "Sprawy Narodowościowe", 1999, nr 14-15.
} 
of cultural contact resulting from conquest, colonization, annexation and migration" (Paleczny, 2007, p. 43). Multiculturalism occurs in societies where multiculturalism is a constant element of social life, but it does not pose any particular interest due to the minimal participation of minorities in public space. But even with their small share in society, change is happening. It breaks the absolute dominance of the majority over minorities, which promotes the manifestation of different cultures. The cultural imagination of the people and the freedom of choices widen. Multiculturalism is the prospect of many alternative choices. It is a clear rejection of assimilation, which forced people to accept a single system of values and norms. Living in contact with many cultures consists of shaping among people the attitudes of tolerance, respect and understanding for the different cultures and people representing them. On the other hand, it should be highlighted that some ethnic (cultural) groups remain at a high axiological and normative distance, which may give rise to antagonisms and conflicts (Szahaj, 2010, pp. 27-30). The social world is transformed under the influence of different ethnic (cultural) groups within its borders. The phenomenon of multiculturalism occurs exclusively in the democratic world. This is a problem of reconciling individualism, which preferred by the liberal-democratic states with a sense of strong community that characterizes peripheral states ${ }^{3}$. Ethnic (cultural) groups are characterized by strong community. They bind individuals strongly, limiting the perspective of their individualism. Such a relation may lead to a great dissonance, when a unit has to decide which way to respect: its own individualism or respecting the idea of community. The choice they will make depends on the degree of internalization of the foundations of the ethnic group of their origin. In the case of a high degree of integration, they will probably choose the community. With weaker integration, the idea of individualism becomes a reality. This is an example of a dilemma that will be accompanied by an increasing number of people. Multiculturalism is an inevitable and increasingly common phenomenon. Ryszard Kapuściński wrote [...] "let us consider whether living in different cultures, civilizations, religions, we want to look for the worst things in other cultures to strengthen our own stereotypes, or we will rather try to find points of contact [...] Our world is at a crossroads. A certain tendency seems inevitable - we will live in a world of multiculturalism" (Domosławski \& Kaczorowski, 2001). Such a world requires action from us, the action which will promote the coexistence of the representatives of cultures in a specific social reality. It is primarily the acceptance of cultural differences, but also the postulate of [...] "equality in the treatment of all citizens in the created individual and collective development opportunities, the abolition of racial barriers and the right of individual minority groups to define and express their unique cultural heritage and identity, among them the language and professed religion occupy the most important place" (Zubrzycki, 2000, p.229). This is a highly desirable image of the space described. Its creation depends on several important issues. Firstly, it depends on the level of saturation of a given space with ethnic diversity. If the saturation level is low, then there are rarely

\footnotetext{
${ }^{3}$ It is a reference to Immanuel Wallerstein's world's system concept, Analiza systemów światów. Wprowadzenie, translated by Katarzyna Gawliczg, Marcin Wielgosz, Dialogue, Warsaw 2007.
} 
problems with substrate related to ethnic (cultural) differences. Secondly, it depends on the cultural distance between the groups. As the distance increases, the threat of ethnic conflict increases. Thirdly, historical past between peoples or ethnic groups are important, as they affect contemporary relationships. Fourthly, it concerns the level of entitlements related to the availability of goods and privileges. A conflict arises when there is a clear difference in access law. These issues may favor or limit the probability of a conflict that disturbs the coexistence of groups of different ethnic (cultural) backgrounds and delays the process of creating a new social order based on ethnic (cultural) diversity.

Multiculturalism is a modern global process whose dynamics can no longer be stopped, but one can prepare well for it. It depends only on policies of individual countries and people, what the multicultural future will be: can we in the diversified world seek and show what connects us, live in peace and create one common but internally differentiated world? Or on the contrary - to indicate what divides us and, inter alia, to cite stereotypes and fears, to provoke antagonisms, divisions and conflicts? The answers to those problems are neither simple nor unequivocal. Multiculturalism is a variety of images, the common denominator of which is the multiplicity of different ethnic cultures, which make up both the past and the present of the world. But it is primarily a phenomenon of the future.

\section{Multiculturalism in a historical sight}

The phenomenon of multiculturalism is not new. It reaches ancient times, though then it was not scientifically analyzed. It was only a phenomenon that created a specific social reality. It is difficult to point to the birth of the phenomenon of multiculturalism, but it is possible to recall its original documentation, which dates back to ancient times, when "it was realized that different societies were characterized by different lifestyles" (Linton, 2007 , p. 403), and when representatives of different cultures lived in the walls of the Pharaoh courts in Egypt. It was most often the result of wars, conquest and migration. The result of these events were the contacts of people from different cultural worlds. Such meetings can be regarded as the beginning of the phenomenon of multiculturalism. It also appeared in ancient Greece - polis, when it came to intercultural relations. On the one hand, there were the citizens of Greek cities, on the other Metics (foreigners). It was similarly among the slaves from different ethnic groups. Herodotus (484 BC - 425 $\mathrm{BC}$ ) realized how culturally diverse world was, when addressing the Greeks: "No, we are not alone - he told the Greeks [...] - we have neighbors, they in turn have their neighbors, and we all populate one planet" (Kapuściński, 2004, p. 203). These are the observations of Herodotus on his journey as he reached different tribes and peoples. He saw their history and culture, which sometimes meet and cross in infinite number of points (Kapuściński, 2004, p. 203).

The original framework of the multicultural phenomenon is also created by the Roman legions. As a result of the recruitment, they had representatives from Dalmatia, Spain, Germany and Syria. Ancient Rome was also the epitome of the city in which the different 
cultural worlds met (Golka, 2010, pp. 66-67). The phenomenon of multiculturalism that began in the ancient world deepened in the next centuries that people's wanders did not stop as well as wars and conquests. They brought together representatives of different cultures in a specific social space. A good example may be the Ottoman Empire, which at the height of territorial development $\left(14^{\text {th }}-20^{\text {th }}\right.$ centuries), has spread on three continents: parts of south-west Asia, northern Africa and south-east Europe. Within the borders of the empire there were diverse religious communities. Each of them ruled by its own rights, recognizing in return the administrative authority of the state and paying for its maintenance (Buchowski, 2008, p. 26). Neither in the ancient times nor in later centuries there was, however, a scientific basis for the elaboration and analysis of multiculturalism. This state changed in Enlightenment. It contributed to the realization, first of all in Europe, of the existence of cultural diversity. The "Persian Letters" by Charles Louis de Secondat Baron de la Brède et Montesquieu (1689-1755) highly contributed in the process. This is a polyphonic epistolary novel consisting of 161 letters written by two Persians wandering across Europe. In the letters they shared their impressions of the journey (1712-1720), writing: "it is a peculiar spectacle for the Mohammedan to watch the first Christian city. I'm not talking about things that hit the front, like the difference of buildings, clothes, and customs: in everything in the smallest details there is something separate, something I feel even though I can not describe it" (de Secondat, n.d., pp. 21-22). These are words about cultural diversity not only of Europe but of the world. The ancient times and later centuries are the oldest intellectual sources of multiculturalism, not based on the theoretical foundations of scientific analysis. In this context Bogdan Szlachta writes that "multiculturalism is an ancient phenomenon. This truism refers us to antiquity, in which we would in vain seek for theoretical projects reminiscent of those formulated today [...]" (Szlachta, 2010, p. 17). Theoretical foundations for contemporary multicultural analysis emerged in the 1970s when multiculturalism was recognized as the foundation of the existence of Canada and Australia.

Ethnic diversity has been associated with societies for centuries and has been an important link in the construction of their social structure. Today's "novelty in policy is to foster the idea that the state should be aware of the cultural diversity that characterizes its population" (Savidan, 2012, p.1). These words confirm the fact that the phenomenon of multiculturalism was present before the theoretical structures and political projects of multiculturalism emerged. Nowadays, this phenomenon is related to the need for individual freedom and participation in culture and the world, which on the one hand is subject to the process of globalization and on the other - to regional integration. It is a fact that ethnic diversity (cultural) is one of the oldest phenomena in the history of mankind. Human beings have always migrated, changing their habitat, and thus differentiating social spaces. On the way of a journey they met further communities with which they either started sharing space or waged war:

In $70 A D$, Jerusalem, one of the largest and most famous cities of its time, bringing together the highest aspirations of the Jewish people, both religious and national after 
a heavy siege was devastated by Roman troops. For the next few centuries the Jews were pushed to the margins of the empire society, and Rome became in their eyes the embodiment of hostile tyranny. Never before in the history of the Roman Empire had such a polarization of two cultures coexisting till that time in conformity happened. (Goodman, 2007, p.7)

This is just one of many examples of the clash of different cultures leading to their antagonistic relationships. Similar dramas of societies do not belong exclusively to the past. The Balkan conflict of the 1990s, or the revolution in the countries of North Africa - Libya or Syria - are more contemporary examples when different ethnic groups had lived in harmony with each other for many years and then suddenly began to fight and mutilate each other. They are very brutal and tragic events, occurring in the context of inter-ethnic relations. It is difficult to prevent them even more if we realize that there are more ethnic groups in the world than countries. There are over 5,000 of the first ones, among them nearly 600 language groups have been singled out. Meanwhile, there are 194 sovereign states (De Swaan, 2001, p.1).

Looking for the beginnings of the phenomenon of multiculturalism one should refer, inter alia, to the work of the Polish sociologist Ludwik Gumplowicz, who not only recognized the diversity of human groups, but recognized them as an important cause of social development. According to him, humanity comes from different groups, which he called races. He borrowed this term from ethnology and social anthropology rather than racist theories, which he was accused of (Gella, 1966, pp. 86-89). The race was not a product of biological and physiological processes for Gumplowicz, but a historical process connected with "unity, which starting point is in the spiritual elements (language, religion, customs, law, culture) and only then comes the most powerful physical element which connects, to the unity of blood" (Gumplowicz, 1910, p.195). The history of mankind begins with the clash of the first hordes of the Homo sapiens. The intensity of the phenomenon was proportional to the degree of group diversity. People naturally were equipped with hatred for all those who belonged to other hordes. By joining one, they were connected by a common culture to create ethnic or national group. The variety that is indicated by Gumplowicz is called polygenism, that is, multitribes. Separate human hordes as a result of fights and wars created larger and more complex communities. The Polish sociologist conceded that conquest and multiplicity are closely related, and that fighting has been a factor of development since the dawn of time "in the primitive times when the human race was made up of countless different tribes and groups, who were fighting all the time and as a result of the forced union of various elements in the state [...]" (Gumplowicz, 1910, p.253). For Ludwik Gumplowicz, the ethnic and cultural diversity of the world had its origins in the concept of polygenesis, to which he remained faithful for many years. Gumplowicz's conception was confronted with the idea of Lester F. Ward, who said that the nature could create only one form of a man, and the differentiation of color, figure, and height is the result of adaptation to different geographical conditions. Humanity has a common origin, but while spreading of the world it has varied ethnically and culturally 
(Gella, 1966, pp. 228-237). Such diversity is on the one hand the foundations of states, whose history is reduced to the struggle of culturally distinct groups. On the other hand, societies as those that in a given space are concentrated in different ethnic and cultural groups. This is another path to the formation of the phenomenon of multiculturalism. Patrick Savidan drew attention to the different path of the formation of multiculturalism. He pointed to the significant dependence of the democratic and national state. As a result of the loss of integration forces by the national state, the democratic state is weakening. It is a condition leading to the weakening of the sovereignty of the state, whose strength is its inclusion in the framework of the nation state. Then ethnic (cultural) diversity is revealed and the primary source of change is the decline of social ties. People start living in harmony with their own ethnic culture, demanding its recognition within the framework of a democratic state.

Today the phenomenon of multiculturalism is seen to some extent as a natural process of meeting the representatives of various ethnos in a particular social space. They live together within the framework of state structures, recognizing each other's social status. It is a reality where there is a dominant culture and ethnic (cultural) groups. Their participation in social life is minimal. No special action is required, neither by the authorities nor by the co-inhabitants. An example of such a defined social reality is Poland.

\section{A phenomenon of multiculturalism: an example of Poland}

The phenomenon of multiculturalism in Poland, as it appears from literature, has a long history of "carrier of ethnicity and multiculturalism, which has grown out of the intuition of researchers from mainly (but not only) Polish perspective, because what appeared in science as ethnicity and multiculturalism is most often found in American social sciences while ethnicity and multiculturalism has its pioneers in Europe, and I will even dare say that in Poland it has its precursors" (Żelazny, 2012, pp. 78-80). Walter Żelazny considers Ludwik Zamenhof (1859-1917) and Ludwik Gumplowicz (1869-1942) as such precursors. It also reaches the times of the Commonwealth of the Two Nations, when Poland was a multinational state. At the same time, it can not be assumed that the Commonwealth was a multicultural society at the time, although we certainly can talk about the phenomenon of multiculturalism. It was the result of religious wars in Europe but also agreements when members of religious minorities - Jews and Karaites (Judaism), Crimean Tatars (Muslims), Mennonites settled in Zulawy (radical Christian croaker) - arrived in Poland from Western Europe. They could freely practice their religion and tradition in Poland. They were not forced to accept Catholicism. Poland had been a multinational state for centuries, although in times it was attempted to diminish its role in social life. The reasons for such actions were political. This note refers to the times after the end of World War II. Before the war, in 1931, the results of the Census indicated that Poles constituted $68.9 \%$ of the population, Ukrainians $-13.9 \%$, Jews $-8.6 \%$, Belarussians $-3.1 \%$, Germans $-2.3 \%$, and other nationalities - 3.2\% (Łodziński, 1995). 
Such population composition of Poland was radically changed after the end of World War II. As a consequence of the extermination of the Nazi ideology towards the Polish people of Jewish origin, as a result of mass movements caused by border changes, forced displacement and voluntary migration, and the policies of the authorities, the number and quantity of national and ethnic minorities decreased markedly. At the turn of the 1960s and 1970s, the Ministry of the Interior - obliged to carry out appropriate statistics - reported that all national and ethnic minorities living in Poland constituted $1.5 \%$ of the total population: 500,000 people. The most numerous were the Ukrainian and Belarussian minorities, whose total number was estimated at 400,000 people. The existence of a German minority was questioned, including only 3,000 people from nonPolish evangelical churches in Pomerania and Lower Silesia. Other estimates from this period assessed the number of people belonging to national and ethnic minorities at 450,000 . It was estimated that there were 180,000 Ukrainians, 165,000 Belarussians, 31,000 Jews, 21,000 Slovaks, 2,000 Czechs, 19,000 Russians, 10,000 Lithuanians, 3,000 Germans, 12,000 Roma (Gypsies) and 10,000 Greeks and Macedonians. However, even such a minor share of the minority was - in postwar Poland (1944-1989) - hidden (Szczepański, 1999, pp. 17-18). The official news was that Poland was a one nation country.

The changes in perception of the level of ethnic (cultural) diversity of Poland took place after 1989. They were, inter alia, the consequence of the following:

1. the abolition of institutional barriers, censorship $(>>$ gag $<<)$ of natural cultural communication, development and choice of their own cultural values in society, 2. changes in the treatment of the citizen by the state connected with the respect of human rights, one of the fundamental ones is the right of every person to his or her own cultural identity. The right to be different includes, but is not limited to, the right to freedom of thought, conscience, religion, teaching, possession and expression the opinions. Thanks to the policy of respecting human rights, cultural minorities are no longer hidden, private and passive, but active, public and demanding, 3. Opening of borders, on the one hand facilitating the importation of new content, values, cultural objects etc., on the other, causing the inclusion of Polish society in the $>>$ international $<<$ and universal culture, 4 . The crisis of the canon $(>>$ center $<<$ ) of Polish culture already described above. Traditional Polish culture slowly loses its center (hierarchy and authority) and takes on a liberal-folk character, for which freedom of expression and local bonds are most important. Polish culture in a descriptive sense becomes more and more >> flattened $<<$, multicentric and regionalized. (Kempny, Kapciak, \& Łodziński, 1997, p. 16)

These changes became apparent in public life and ethnic (cultural) differences began to openly contribute to the image of society. Today Poland is a nation state with ethnic and national minorities. It is an example of social space in which multiculturalism is present. The results of the National Population and Housing Census of 2002 also indicate this. For the first time, Poles were asked about national identity and a language used at home. 
Obtained data showed that $1.23 \%$ of the inhabitants of Poland declared other than Polish nationality. The largest number of declarations concerned the German minority. At the same time, $1.47 \%$ of the Polish population said that they used a language other than Polish in their family contacts. Most often it was German and English (Janusz, 2011, pp. 131-133). The second Census in XXI century (2011) revealed that in Poland were $2.19 \%$ of people declaring jointly Polish and non-Polish national identity and $1.46 \%$ declaring exclusively non-Polish nationality (Narodowy Spis Powszechny Ludności i Mieszkań, n.d.). It's a slight increase but comparing to 2002 - noticeable.

The largest number involved the identification of Silesian and Kashubian and the smallest of Spanish and Dutch (Gudaczewski, 2015, p. 66). In the case of declarations of belonging to the Silesian nationality, in 2002 there were 173,153. The largest number in the Silesian Voivodship $(148,500)$ and Opolskie $(24,200)$. Also in the area of the Polish part of Cieszyn Silesia (Cieszyn District, Bielsko-Biala District, Bielsko-Biala), 1045 people declared their Silesian nationality (Wyniki Narodowego Spisu Powszechnego Ludności i Mieszkań, 2002). The National Census of 2011 made it possible to identify a complex ethnic identity. This was not possible in 2002. Probably this change, among other things, caused the Silesian nationality to be declared by 817,000 people in 2011, among them 362,000 as the only one. Silesian national identity was declared as the first one by 418,000 people (Narodowy Spis Powszechny Ludności i Mieszkań, 2011). Similar changes occurred in Kashubian identification. In the year 2002 there were 5,062 such identifications, and in 2011 there were 232,547 of them, of which 16,377 indicated the Kashubian minority as the only national identification group (Kaszebsko.com, n.d.). Such results show the real level of ethnic (cultural) diversity in Poland. It is small, which authorizes Walter Connor to describe Poland in a justified way, with such states as Iceland as a nation state (Connor, 1994, p. 96). The level of ethnic (cultural) diversity of Poland practically excludes the occurrence of problems related to multiculturalism. This situation may change in the context of the wave of refugees and immigrants arriving in Europe. Poland, as a member of the European Community, has certain obligations in this regard. This results, for example, from the fact that Poland signed the Geneva Convention on the Status of Refugees of July 28, 1951. Poland joined the Convention on September 2, 1991, and the act itself states, among others, the principle that "all people without discrimination should benefit from fundamental rights and freedoms" (Internetowy System Aktów Prawnych, n.d.).

In 2017, the level of ethnic diversity in Poland does not require special actions from the state administrative structures. However, Poland has two important documents defining the rights of national and ethnic minorities. In the Constitution in Art. 35 there is the record:

1. The Republic of Poland assures Polish citizens belonging to national and ethnic minorities the freedom to preserve and develop their own language, preserve customs and traditions and develop their own culture. 2. National and ethnic minorities have the right to establish their own educational, cultural and religious institutions and to 
participate in the settlement of matters relating to their cultural identity. (Konstytucja Rzeczypospolitej Polskiej, 2010, pp. 13-14)

Poland allows representatives of ethnic and national minorities who are citizens of Poland to cultivate their traditions within the Polish society. It does not mention minority members who do not have Polish citizenship. By defining the rights of minorities simultaneously in the preamble to the Basic Law of April 2, 1997 Poland puts believing Poles on the first place "we, the nation of Poland - all citizens, both believers in God, the source of truth, justice, good and beauty, and not relying on this faith, and these universal Values derived from other sources [...]" (Konstytucja Rzeczpospolitej Polskiej, n.d.). This is a record emphasizing the dominant role of the Polish people and its culture (Buchowski, 2008, p.37). For comparison, the Constitution of Canada, which is a multicultural society, begins with the words:

Whereas Canada has been created in accordance with the principles of God's sovereignty and the rule of law [...] the Canadian Charter of Rights and Freedoms guarantees the rights and freedoms it expresses and subject only to such limitations which are set by law and have clear justification in a free and democratic society. [...] Everyone has the following fundamental freedoms: (a) freedom of conscience and religion; (b) freedom of thought, believes and expression of opinions, including freedom of the press and other means of communication; (c) freedom of peaceful assembly; (d) freedom of association. (Konstytucja Rzeczpospolitej Polskiej, 1998, p.94)

The Polish and Canadian Constitution's submissions show the fundamental difference between the two societies. Poland, which is characterized by the phenomenon of multiculturalism, clearly indicates the national foundations of society and the state. Canada, on the other hand, is a formal multicultural society, born of a long process of immigration, where there is no single, national (cultural) domination.

In 2005, a special law on national and ethnic minorities and regional language was adopted in Poland (Ustawa, 2005). The law fully respects the rights and obligations of minorities living in Poland. It defines, among other things, the concept of national minorities it recognizes nine national and ethnic minorities - it recognizes four ethnic minorities and one regional language (Kashubian). Indicates "that it governs the preservation and development of cultural identities of national and ethnic minorities and the preservation and development of the regional language, as well as the manner of implementing the principle of equal treatment of people irrespective of ethnicity and defines the tasks and powers of governmental and local government bodies in connection with these matters" (Ustawa, 2005, roz. 1, art. 1). The law also explicitly prohibits discrimination on grounds of national or ethnic affiliation. Such a prohibition is also in the 1997 Constitution and the Penal Code. However, there are situations when in practice these prohibitions seem dead. But it should also be stressed that many of the discriminatory behavior of Poles against immigrants or refugees is finalized in the courts. An example is the verdict for the 
perpetrators of beating students from Turkey in Torun. They came to Poland thanks to the Erasmus program.

The Constitution of the Republic of Poland and the Act on National and Ethnic Minorities and Regional Language fulfill the needs of national and ethnic minorities in Poland. Although the Minority Act is subject to various amendments, it does not change the essential part. Strong domination of Polish national culture and the low participation of national and ethnic minorities do not require the adoption of special political projects. It does not, however, free Poles from showing understanding and sensitivity to any ethnic or national issues. It is particularly important in the context of the contemporary problems of refugees and migrants coming to Europe. Poland should in this regard be guided by solidarity with the countries of the European Union. Today Poland remains a society in which multiculturalism occurs.

The phenomenon of multiculturalism arouses different attitudes among people, although they are rarely extreme. As the participation of minorities in society life is not big, so it does not raise fears of different cultures. They do not change the established social order but only integrate into existing state and administrative structures and rules of socio-cultural life. Hence the level of their acceptance in society is high. Minorities live within the boundaries of a dominant culture respecting its laws. They can manifest their cultural distinctiveness. They can have their own religion and use their own languages. This arrangement ensure the easy coexistence of representatives of different cultures, although minor antagonisms also occur. An example of such a constituted society and state is Poland today.

\section{References:}

Australian Ethnic Affairs Council: Australia as a Multicultural Society - Submission to the Australian Population and Immigration Council on the Green paper, Immigration Policies and Australia's Population (1997). (Chairman J. Zubrzycki). Canberra: Australian Government Publishing Service.

Buchowski, M. (2008). Antropologiczne kłopoty z multikulturalizmem. In H. Mamzer (Ed.), Czy klęska wielokulturowości? (pp. 15-51). Poznań: Wydawnictwo Fundacji Humaniora.

Connor, W. (1994). Ethnonationalism: The Quest for Understanding. Princeton: Princeton University Press.

De Secondat, Ch. L., baron de la Brède et de Montesquieu. Listy perskie. Fundacja Nowoczesna Polska, [online]. Accessed 14 February 2016. Retrieved from https:// wolnelektury.pl/media/book/pdf/listy-perskie.pdf 
De Swaan, A. (2001). Words of the World. The Global Language System. London: Polity Press. [online]. Accessed 11 February 2016. Retrieved from http://państwa.suder.cc.

Debates. 12 October 1971 (1971). Ottawa: Queen's Printer.

Domosławski, A., \& Kaczorowski A. (2001, September 29-30). Nasz kruchy świat (an interview with Ryszard Kapuściński), Gazeta Wyborcza, p. 8.

Gella, A. (1966). Ewolucjonizm a początki socjologii (L. Gumplowicz and L. F. Ward). Wrocław - Warszawa - Kraków: Polska Akademia Nauk, Ossolineum.

Golka, M. (2007). Socjologia kultury. Warszawa: Scholar.

Golka, M. (2010). Imiona wielokulturowości. Warszawa: Warszawskie Wydawnictwo Literackie MUZA SA.

Goodman, M. (2007). Rzym i Jerozolima. Zderzenie antycznych cywilizacji. Warszawa: Wydawnictwo Magnum.

Gudaszewski, G. (2015). Identyfikacje etniczne w Narodowym Spisie Powszechnym Ludności i Mieszkań w 2011 roku. In S. Łodziński, K. Warmińska, \& G. Gudaszewski (Eds.), Mniejszości narodowe i etniczne w Polsce w świetle Narodowego Spisu Powszechnego Ludności z 2011 roku (pp. 56-119). Warszawa: Scholar.

Gumplowicz, L. (1910). Filozofia społeczna. Warszawa.

Hałas E. (2015). Przez pryzmat kultury. Dylematy badań nad współczesnością, Warszawa: Wydawnictwa UW.

Internetowy System Aktów Prawnych. [online]. Accessed 12 March 2017. Retrieved from www.isap.sejm.gov.pl/DetailsServlet?id=WDU19911190515.

Ivison D. (2010). Introduction: Multiculturalism as a Public Ideal. In D. Ivison (Ed.), The Ashgate Research Companion to Multiculturalism (pp. 1-16). Farnham - Burlington: Ashgate.

Janusz G. (2011). Ochrona praw mniejszości narodowych w Europie. Lublin: Wydawnictwo Uniwersytetu Marii Curie-Skłodowskiej.

Kapuściński R. (2004). Podróże z Herodotem. Kraków: Znak.

Kaszëbskô Jednota I Stowarzyszenie Osób Narodowości Kaszubskiej. [online]. Accessed 12 March 2017. Retrieved from www.Kaszebsko.com/uploads/Kaszubskieidentyfikacjenarodowo-etniczne.pdf.

Kempny M., Kapciak A., \& Łodziński S. (1997). Wprowadzenie. Społeczeństwo polskie na progu wielokulturowości. In M. Kempny, A. Kapciak, \& S. Łodziński (Eds.), U progu wielokulturowości. Warszawa: Oficyna Naukowa. 
Konstytucja Kanady (1998), translated by J. Osiński, \& I. Zawiślińska. Warszawa: Biblioteka Sejmowa, Wydawnictwo Sejmowe.

Konstytucja Rzeczypospolitej Polskiej z dnia 2 kwietnia 1997 r. art. 35, (2010). Warszawa: Wydawnictwo Sejmowe.

Konstytucja Rzeczpospolitej Polskiej z 2 kwietnia 1997 roku. [online]. Accessed 14 April 2016. Retrieved from www.isap.sejm.gov.pl.

Linton, R. (2007). Pojęcie kultury. In E. Nowicka, \& M. Głowacka-Grajper (Eds.), Świat człowieka świat kultury. Antologia tekstów klasycznej antropologii (pp. 403-417). Warszawa: Wydawnictwo Naukowe PWN.

Łodziński, S. (1995). Polityka państwa polskiego wobec mniejszości narodowych w latach 1989-1993 ( $\mathrm{Na}$ tle rozwiązań prawnych obowiązujących w państwach europejskich i regulacji przygotowywanych w ramach prac Rady Europy). Przegląd Polonijny, 1995(1).

Mucha, J. (1999). Wielokulturowość etniczna i nieetniczna. Sprawy Narodowościowe, 1999 (14-15).

Mucha, J. (2005). Oblicza etniczności. Studia teoretyczne i empiryczne. Kraków: Nomos.

Narodowy Spis Powszechny Ludności i Mieszkań 2011. Raport. [online]. Accessed 9 June 2013. Retrieved from www.stat.gov.pl/cps/rde/xbcr/gus/lud_raport_z_wynikow_ NSP2011.pdf.

Narodowy Spis Powszechny Ludności i Mieszkań. [online]. Accessed 12 January 2016. Retrieved from www.stat.gov.pl/cps/rde/xbcr/gus/lud_raport_z_wynikow_NSP2011.pdf.

Paleczny, T. (2007). Współczesne społeczeństwo amerykańskie w perspektywie socjologicznej. Kraków: Wydawnictwo Uniwersytetu Jagiellońskiego.

Rokicki, J. (1996). Współczesne trendy badań socjologicznych problemów rasy i etniczności w Stanach Zjednoczonych Ameryki. Przegląd Polonijny, 1996(2), 111-124.

Sadowski, A. (1999). Zróżnicowanie społeczne a społeczeństwo obywatelskie. Sprawy Narodowościowe, 1999(14-15), 31-41.

Sadowski, A. (2011). Społeczeństwo polskie - od zróżnicowanego kulturowo do wielokulturowego. Szanse i zagrożenia. In A. Śliz, \& M. S. Szczepański (Eds.), Wielokulturowość: konflikt czy koegzystencja? (pp. 48-73).Warszawa: Wydawnictwo IFiS PAN.

Savidan, P. (2012). Wielokulturowość. (trans. by E. Kozłowska). Warszawa: Oficyna Naukowa.

Szahaj, A. (2010). Wielokulturowość: za i przeciw (Kilka uwag). In D. Pietrzyk-Reeves, \& M. Kułakowska (Eds.), Studia nad wielokulturowością (pp. 25-30). Kraków: Księgarnia Akademicka. 
Szczepański, M. S. (1999). "Inni swoi". Szkic do socjologicznego portretu mniejszości narodowych w Polsce. In D. Berlińska, \& K. Frysztacki (Eds.), Inni Swoi. Studia z problematyki etniczne. Opole: Stowarzyszenie Instytut Śląski, Państwowy Instytut Naukowy - Instytut Śląski w Opolu.

Szlachta, B. (2010). Kłopoty z wielokulturowością. In D. Pietrzyk-Reeves, \& M. Kułakowska (Eds.), Studia nad wielokulturowością (pp.17-23). Kraków: Księgarnia Akademicka.

Ustawa z dnia 6 stycznia 2005 r. o mniejszościach narodowych i etnicznych oraz o języku regionalnym. [online]. Accessed 12 January 2016. Retrieved from www.isap.sejm.gov.pl/ DetailsServlet?id=WDU20050170141.

Wallerstein, I. (2007). Analiza systemów światów. Wprowadzenie. (trans. by K. Gawliczg, \& M. Wielgosz). Warszawa: Dialog.

Wyniki Narodowego Spisu Powszechnego Ludności i Mieszkań 2002. Główny Urząd Statystyczny, [online]. Retrieved from www.stat.gov.pl.

Znaniecki, F. (2008). Metoda socjologii. (trans. by E. Hałas). Warszawa: Wydawnictwo Naukowe PWN.

Zubrzycki, J. (2000). Multiculturalism. Ethnic Diversity and Italian Australian. Ethnic Heritage. In P. Genovesi, \& W. Musolino (Eds.), Search of the Italian Australian into the New Millenium (pp. 227-237). Melbourne: Gro-Set Pty.

Żelazny, W. (2012). Przednaukowe postrzeganie etniczności i wielokulturowości. Heterogeniczne źródła zjawiska. In M. Biernacka, K. Krzysztofek, \& A. Sadowski (Eds.), Społeczeństwo wielokulturowe - nowe wyzwania i zagrożenia. Białystok: Wydawnictwo Uniwersytetu w Białymstoku.

\section{Authors}

dr hab., prof. UO Anna Śliz

Faculty of Social Sciences, University of Opole

Department of Sociology

Katowicka 89, 45-061 Opole, Poland

asliz@uni.opole.pl

prof. zw. dr hab. Marek S. Szczepański

Faculty of Social Sciences, University of Silesia

Department of Sociology

ul. Bankowa 11, 40-007 Katowice, Poland

marek.s.szczepanski@us.edu.pl 